\title{
BMJ Open What is the evidence for the impact of gardens and gardening on health and well-being: a scoping review and evidence-based logic model to guide healthcare strategy decision making on the use of gardening approaches as a social prescription
}

To cite: Howarth M, Brettle A, Hardman $\mathrm{M}$, et al. What is the evidence for the impact of gardens and gardening on health and well-being: a scoping review and evidence-based logic model to guide healthcare strategy decision making on the use of gardening approaches as a social prescription. BMJ Open 2020;10:e036923. doi:10.1136/ bmjopen-2020-036923

- Prepublication history and additional material for this paper are available online. To view these files, please visit the journal online (http://dx.doi. org/10.1136/bmjopen-2020036923).

Received 10 January 2020

Revised 20 May 2020

Accepted 21 May 2020
Check for updates

(C) Author(s) (or their employer(s)) 2020. Re-use permitted under CC BY-NC. No commercial re-use. See rights and permissions. Published by BMJ.

For numbered affiliations see end of article.

Correspondence to Dr Michelle Howarth; M.L.Howarth2@salford.ac.uk

\section{ABSTRACT}

Objective To systematically identify and describe studies that have evaluated the impact of gardens and gardening on health and well-being. A secondary objective was to use this evidence to build evidence-based logic models to guide health strategy decision making about gardens and gardening as a non-medical, social prescription.

Design Scoping review of the impact of gardens and gardening on health and well-being. Gardens include private spaces and those open to the public or part of hospitals, care homes, hospices or third sector organisations.

Data sources A range of biomedical and health management journals was searched including Medline, CINAHL, Psychinfo, Web of Knowledge, ASSIA, Cochrane, Joanna Briggs, Greenfile, Environment Complete and a number of indicative websites were searched to locate context-specific data and grey literature. We searched from 1990 to November 2019.

Eligibility criteria We included research studies (including systematic reviews) that assessed the effect, value or impact of any garden that met the gardening definition.

Data extraction and synthesis Three reviewers jointly screened 50 records by titles and abstracts to ensure calibration. Each record title was screened independently by 2 out of 3 members of the project team and each abstract was screened by 1 member of a team of 3 . Random checks on abstract and full-text screening were conducted by a fourth member of the team and any discrepancies were resolved through double-checking and discussion. Results From the 8896 papers located, a total of $77^{\star}$ studies was included. Over 35 validated health, wellbeing and functional biometric outcome measures were reported. Interventions ranged from viewing gardens, taking part in gardening or undertaking therapeutic activities. The findings demonstrated links between gardens and improved mental well-being, increased physical activity and a reduction in social isolation enabling the development of 2 logic models.
Strengths and limitations of this study

- This is the first scoping review to explicate the breadth and depth of evidence about the impact of gardens and gardening on a range of health and well-being outcomes.

- Gardening as a construct lacks definition leading to associated challenges with the location and curation of papers.

- Lack of a 'standardised' garden or gardening approach has influenced a myriad of research designs, preventing meta-analysis.

- Our paper provides robust evidence-based guidance via logic models to guide health strategy decision making.

Conclusions Gardens and gardening can improve the health and well-being for people with a range of health and social needs. The benefits of gardens and gardening could be used as a 'social prescription' globally, for people with long-term conditions (LTCs). Our logic models provide an evidence-based illustration that can guide health strategy decision making about the referral of people with LTCs to socially prescribed, non-medical interventions involving gardens and gardening.

\section{RATIONALE}

Long-term conditions (LTCs), also referred to as chronic diseases, such as cardiovascular disease, chronic respiratory disorders and cancer, remain a significant cause of death globally. ${ }^{1}$ Contributing to these figures, mental ill-health is the largest single cause of disability worldwide representing $14 \%$ of the global population, with depression accounting for $4.3 \% .^{2}$ Socioeconomic factors such as education and employment 
can also influence health and well-being and health inequalities, and can often lead to increased risk of chronic conditions. ${ }^{3}$

In the UK, the management of LTCs is challenged by unmet social needs which are attributed to increased attendance at General Practitioner (GP) surgeries. ${ }^{4}$ Patients with LTCs require multipurpose, complex interventions combining interprofessional and intra-agency responses. Hence, it is predicted that LTCs will outstrip universal health and social care service provision, forcing healthcare strategists to appraise the effectiveness of existing pathogenic interventions. However, the traditional medical management of people with LTCs does not tackle their social needs leading to repeat primary care appointments and unnecessary admissions to secondary care. ${ }^{5}$ Consequently, there is a demand to explore alternative, non-medical, salutogenic (non-pathogenic) global approaches that could empower patients with LTCs to reduce their dependence on health and social care services. ${ }^{6}$

Social prescribing is a non-medical method of care which 'links patients in primary care with sources of support within the community to help improve their health and well-being., This salutogenic process focuses on promoting well-being by referral to a range of non-medical approaches, from exercise on prescription, to arts-based activities and beyond. ${ }^{6-9}$ The complex relationship between health communities and its citizens is largely influenced by wider social determinants. ${ }^{10}$ Place-based community organisations which invest in the community are able to respond to and support the wider social determinants of health. ${ }^{10}$

A popular social prescribing approach offered by placebased organisations is the use of gardens and gardening as a nature-based activity to improve health and well-being. ${ }^{11}$ The use of nature as an intervention is increasingly being recognised worldwide as a means of improving social, emotional, mental and physiological outcomes and is of potential value for people with LTCs. In a recent metaanalysis by Soga $e t a l$, the impact of gardening and gardens on a range of physical and mental health outcomes was demonstrated to have positive health and well-being benefits. ${ }^{11}$ However, this meta-analysis only considered a limited range of methodologies, focusing on papers that compared health outcomes in control and treatment groups after participating in gardening. Typically, nature-based interventions comprise a broad spectrum of interventions, activities and outcomes that include plants, the natural environment and living creatures, and of interest here, is the recognition that gardening supports people with LTCs. ${ }^{12}$ People with chronic conditions can engage in nature through being in gardens and through gardening activities such as allotment gardening ${ }^{13}$ to guerrilla gardening ${ }^{14}$ and community gardening. ${ }^{15}$ Gardens are used to cultivate flowers, exercise, connect with others and grow food. In this article, we adopt this broad definition of gardening and evaluate the full range of interventions within our scoping review. In doing so, we produce a range of logic models and results to demonstrate the benefit of different forms of gardening across the globe.
To date, there have been no studies that have specifically explored the breadth of literature about the effectiveness of gardens and gardening that could help prevent the impact of rising levels of chronic disease.

\section{REVIEW AIM AND OBJECTIVES}

Our scoping review aimed to identify and describe the evidence base on the impact of gardens and gardening on the physical and mental health and well-being of populations. The objectives were to understand the benefits of gardens, provide a map of the literature, types of gardens and health outcomes and build evidence-based logic models to guide healthcare strategists' decision to use of gardens and gardening as a non-medical, social prescription. We agreed on the following review question 'What evidence is there on the physical, mental, health and well-being benefits of gardens?'.

\section{METHODS}

To address the global gap in evidence, we employed a scoping review methodology. Scoping reviews provide a systematic and robust means of reviewing the breadth of evidence in a wide field and are useful in synthesising the increasing arsenal of evidence, in contrast to a more traditional systematic review that focuses on answering a particular question. ${ }^{16}$ We employed Arksey and O'Malley's validated framework to map the evidence. ${ }^{17}$ This was particularly relevant as the aim of the scoping review was to explicate the impact of gardens and gardening on diverse outcomes and populations. The resultant map of the evidence was used to develop evidence-based logic models to illustrate the key health and well-being outcomes as graphic tools to support clinician and commissioner decision making. ${ }^{18}$ The initial scoping review framework was refined to provide an appropriate method based on the following steps. ${ }^{19}{ }^{20}$ This involved: 1 . Identifying the research question. 2. Identifying relevant studies. 3. Study selection. 4. Charting the data. 5. Collating, summarising and reporting the results. 6 . Consultation. Stages $1-4$ were conducted iteratively. Stage 5 was undertaken following stages 1-4 and stage 6 (consultation) occurred throughout the lifetime of the review between our research team and our external national stakeholder. Boxes 1 and 2 detail the databases and journals searched.

\section{Search and selection of studies}

We undertook a comprehensive and iterative search to capture the range of perspectives relating to gardens. We searched from 1990 onwards to capture evidence as recommended by Arksey and O'Malley. ${ }^{17}$ In April 2017, we searched 15 electronic databases and six key journals capturing health, social, psychological and environmental perspectives, grey literature sources and websites (including Google Scholar). We repeated the search in September 2018 and November 2019 to capture additional literature published. It is recommended that 


\section{Box 1 Databases searched}

Database name
MEDLINE
CINAHL
PsychINF0
Web of Knowledge/Science
Scopus
HMIC
Science Direct
Social Care Online
ASSIA
Cochrane Database of Promoting Health Effectiveness Reviews
Joanna Briggs systematic reviews
Greenfile
Environment Complete
AMED
Social Policy and Practice

scoping reviews engage interprofessional teams as they bring a breadth and depth of knowledge ${ }^{19}$ Correspondingly, our team was interdisciplinary with subject and methodological expertise comprising a nurse with experience in social prescribing and nature-based approaches, a geographer with expertise in urban agriculture and sustainable cities, and two health information specialists with additional expertise in systematic review methodology. Our external stakeholder was a national body representing a wide range of gardening interests. We defined gardens as being:

intimate private spaces attached to private households but they can also be large private or formal gardens open to the public, or part of hospitals care homes or hospices. ${ }^{21}$

\section{Box 2 Journals searched}

- International Journal of Agricultural Sustainability

- Journal of Environmental Planning and Management

- Health and the Natural Outdoors

- Journal of Environmental Psychology

- Psychological Science

- Environment and Behaviour

- Environmental Health Perspectives

- Landscape and Urban Planning

- Urban Forestry and Urban Greening

- Journal of Social Issues

- International Journal of Environment and Health

- International Journal of Environmental Health Research

- International Journal of Environmental Research and Public Health

- Journal of Public Health

- Public Health

Environmental Science and Technology

- Journal of Epidemiology and Community Health

Health and Place

Environmental Sciences
We modified the protocol throughout the initial search and filtering process to ensure the project remained manageable and faithful to the initial research question and definitions. We searched in a wide and sensitive manner to encompass the diverse types of gardens that could be located within green space or nature-based type of activities. A range of thesaurus and free-text terms (adapted per database) to describe the different types of gardens, and potential breadth of health outcomes were used (see online supplementary appendix for example). To ensure robustness, our search followed the agreed protocol and the results were stored on Endnote web reference management software function to manage and track references throughout the scoping review process which was shared across the project team. We recorded search strategies with details of the date the search was undertaken and the number of results obtained and issues arising during the searching to provide a complete history of the search process and provide transparency of the review process.

We agreed an initial set of inclusion and exclusion criteria following the scoping searches and set these out in the protocol. A study was included if it met the definition of gardens, ${ }^{21}$ had a measurable outcome on health or well-being, and was published in English after 1990. Ultimately, gardens comprise numerous interacting components, outcomes and populations and may be described as complex interventions. ${ }^{22}$ We therefore ensured that there were no restrictions on study design, biometric indicators or population groups. Systematic reviews summarise the results of studies answering a focused question and within the evidence-based healthcare policy context, they are acknowledged as 'gold standard' evidence, ${ }^{23}$ no systematic reviews covered the breadth of our review question, so they were included as studies in their own right. We searched for non-experimental and quasi-experimental studies, which included non-equivalent control group pretest post-test studies and single group non-controlled designs ${ }^{19}$ and studies that determined causality through non-randomisation. We excluded other green spaces such as forests or parks and studies on access to green spaces or living near green spaces. We excluded biological indicators of soil or plants, dissertations, theses, conference presentations, abstracts or posters. We also excluded studies which used process indicators rather than health outcomes and studies which included gardening as part of other interventions where the effects could not be separated.

Three reviewers ( $\mathrm{AB}, \mathrm{MHo}, \mathrm{MHa})$ jointly screened 50 records by titles and abstracts to ensure calibration. Once this was achieved each record title was screened independently by two out of three members of the project team ( $\mathrm{AB}, \mathrm{MHa}, \mathrm{Mho})$, then each abstract was screened by one member of a team of three (AB, MHa, Mho), and full-text screening was conducted by one member of a team of three ( $\mathrm{AB}, \mathrm{MHa}, \mathrm{Mho})$. Random checks on abstract and full-text screening were conducted by a fourth member of the team (MM). Any discrepancies were resolved through double-checking and discussion. 

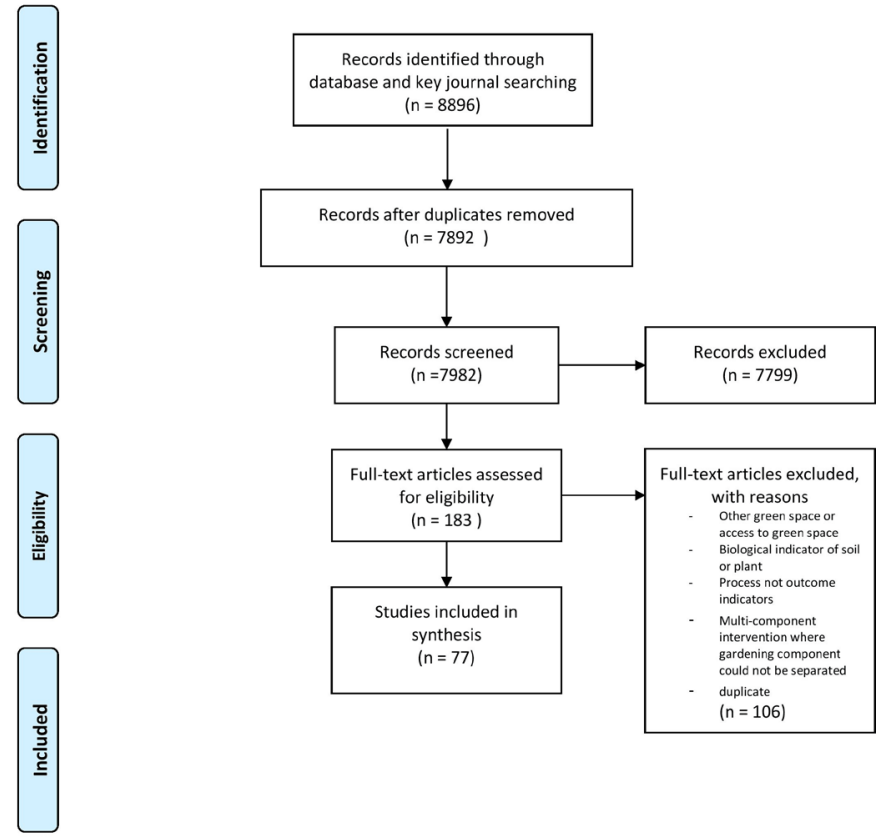

Figure 1 PRISMA diagram: searching and sifting process (adapted from Moher et al $\left.{ }^{24}\right]$ ). PRISMA, Preferred Reporting Items for Systematic Reviews and Meta-Analyses.

\section{Charting, collating and summarising the data}

We used Microsoft Excel to create a data extraction template that could automatically populate evidence tables. Through team discussion we agreed on elements to extract (column headings) based on study characteristics, green space characteristics, intervention characteristics, health condition, age group, outcome measures, findings and author conclusions. When reporting findings for experimental studies, effect sizes and CIs were included as appropriate; for systematic reviews and other designs narrative findings were reported. One member of the project team (MM) extracted all the data up to 2017 and MHo to 2019. We used the evidence tables to organise and synthesise the data to enable us to map the benefits of gardens in relation to different types of gardens, health outcomes (physical, mental and well-being) and health conditions.

\section{Consultation with partners and patients}

We engaged local nature-based partners throughout this review process. We involved a national nature-based stakeholder organisation in developing the review protocol and presented and sought feedback on the results at an Economic Social Research Council funded event of community leaders (including the national stakeholder organisation), third sector organisations, the general public and public health representatives with an interest in gardens and gardening.

\section{Patient and public involvement}

This research was done without patient involvement. Patients were not invited to comment on the study design and were not consulted to develop patient-relevant outcomes or interpret the results. Patients were not invited to contribute to the writing or editing of this document for readability or accuracy. However, we consulted the general public through a community engagement event with residents and local providers of gardening programmes.

\section{RESULTS}

\section{Search results}

From 8896 citations, we located 77 full-text studies* (figure 1). ${ }^{24}$

\section{Description of studies}

A total of 77 studies was included in this review. ${ }^{11}$ 25-100 Country of origin included the UK, USA, Brazil, South Korea, Taiwan, Japan and the Netherlands. All the studies described complex interventions, using heterogeneous methodologies, comprising 14 types of study designs. The scoping review highlights the methodological challenges associated in determining causality with complex interventions. There was an even split between experimental/ quasi-experimental (29\%) and non-experimental studies located $(37 \%)$. Non-equivalent control group and single group pretest, post-test were the most frequently used quasi-experimental study designs $(20 \%)$. There were 8 randomised controlled trials ( $9 \%)^{2831354356596596}$ and 13 (16\%) systematic reviews. ${ }^{26} 324244606475838690949798$ All, barring one ${ }^{60}$ of the systematic reviews reported heterogeneous complex interventions. We present two evidencebased tables detailing higher-level evidence from systematic reviews and randomised controlled trials (see tables 1 and 2); full evidence tables available from authors on request.

\section{Description of gardening interventions}

The scoping framework ${ }^{17}$ enabled us to locate and include a broad range of evidence, likewise, using the predetermined $^{21}$ definition of gardens enabled the capture of diverse types of gardens. Typical gardening interventions included 'allotment gardening' $(\mathrm{n}=8)$ and 'Community gardens' $(\mathrm{n}=11)$. The most common garden intervention reported was horticultural therapy $(n=17)$ which integrates a structured gardening programme with qualified therapist input. The second most popular approach was 'structured gardening' $(\mathrm{n}=17)$ which provides a structured programme of activities but does not include a qualified therapist. Irrespective of garden 'type' all garden activities were characterised through a range of physical activities such as 'planting seeds', 'potting on', 'taking cuttings', 'pricking out', 'sweeping and maintaining the garden', 'using and cleaning tools' and other similar tasks.

\section{Description of outcome types}

We located a range of study methods which reported outcomes related to mental health, physical impact, nutritional behaviour changes and overall general well-being. There were over 35 validated health and well-being outcome measures reported. Most papers examined the impact of 
Table 1 Evidence summary: randomised controlled trials

\begin{tabular}{|c|c|c|c|c|c|c|}
\hline $\begin{array}{l}\text { Author, date } \\
\text { and country }\end{array}$ & Study aims & Garden type & Age & Outcomes measured & Key findings & Author conclusions \\
\hline $\begin{array}{l}\text { Detweiler et } \\
\text { al, USA }{ }^{35}\end{array}$ & $\begin{array}{l}\text { To assess the effect } \\
\text { of horticultural } \\
\text { therapy on cortisol } \\
\text { levels, depression, } \\
\text { symptoms of } \\
\text { post-traumatic } \\
\text { stress disorder, } \\
\text { alcohol cravings, } \\
\text { and quality of } \\
\text { life symptoms } \\
\text { compared with a } \\
\text { non-horticultural OT } \\
\text { group. }\end{array}$ & $\begin{array}{l}\text { Structured } \\
\text { gardening } \\
\text { programme }\end{array}$ & $\begin{array}{l}\text { Mean age } \\
46.4 \text { years } \\
(S D=11.9)\end{array}$ & $\begin{array}{l}\text { Quality of life (Quality of Life } \\
\text { Enjoyment and Satisfaction } \\
\text { Questionnaire - Short Form } \\
\text { (Q-LES-Q-SF)), alcohol } \\
\text { craving (Alcohol Craving } \\
\text { Questionnaire (ACQ-NOW), } \\
\text { PTSD (Posttraumatic Stress } \\
\text { Disorder Checklist Civilian } \\
\text { Version (PCLC)), depression } \\
\text { (Centre for Epidemiologic } \\
\text { Studies Depression Scale } \\
\text { (CES-D)), outcomes } \\
\text { assessed pretreatment and } \\
\text { post-treatment. Salivary } \\
\text { cortisol samples were taken } \\
\text { at weeks 1, 2,and } 3\end{array}$ & $\begin{array}{l}24 \text { participants completed } \\
\text { protocol. Although a positive } \\
\text { impact of HT was seen in } \\
\text { a } 12 \% \text { reduction in salivary } \\
\text { cortisol levels from week } 1 \text { to } \\
\text { week } 3 \text {, the difference was not } \\
\text { statistically significant (analysis } \\
\text { of variance (ANOVA) (F2, } \\
20=0.878), p=0.43 \text { ). Separate } \\
\text { one-way analyses of covariance } \\
\text { (ANCOVAs) found no statistically } \\
\text { significant differences in the } \\
\text { self-administered tests. } A \\
\text { positive trend was seen in } \\
\text { improving quality of life and } \\
\text { depressive symptoms in } \\
\text { the HT group }(Q-L E S-Q-S F, \\
p=0.001 \text { and CES-D, } p<0.001) \\
\text { compared with the OT group } \\
\text { (Q-LES- } Q-S F, p=0.029 \text { and } \\
\text { CES-D, } p=0.050) . H T \text { group } \\
\text { did not significantly improve in } \\
\text { ACQ-NOW ( } p=0.118 \text { ), whereas } \\
\text { the OT group did ( } p=0.040 \text { ). HT } \\
\text { group did significantly improve } \\
\text { in PCLC ( } p=0.039 \text { ), whereas the } \\
\text { OT group did ( } p=0.135 \text { ) }\end{array}$ & $\begin{array}{l}\text { HT may have a role } \\
\text { in reducing stress } \\
\text { and depression and } \\
\text { quality of life more } \\
\text { than the programmes } \\
\text { in which the OT } \\
\text { participated }\end{array}$ \\
\hline $\begin{array}{l}\text { Jarrott et al, } \\
\text { USA }^{56}\end{array}$ & $\begin{array}{l}\text { To compare a } \\
\text { randomly assigned } \\
\text { treatment group, } \\
\text { that received } \\
\text { horticultural } \\
\text { therapy-based } \\
\text { programming to a } \\
\text { comparison group, } \\
\text { that engaged in } \\
\text { traditional activities } \\
\text { programming, on } \\
\text { engagement and } \\
\text { affect }\end{array}$ & $H T^{* *}$ & $\begin{array}{l}\text { Mean age of } \\
80.09 \text { years } \\
(\mathrm{SD}=8.05)\end{array}$ & $\begin{array}{l}\text { Level of cognitive impairment } \\
\text { (Mini-Mental Status Exam) } \\
\text { Affect (Apparent Affect } \\
\text { Rating Scale) Engagement } \\
\text { (Menorah Park Engagement } \\
\text { Scale) Observations took } \\
\text { place twice a week during } \\
\text { weeks 1, 2,5 and } 6\end{array}$ & $\begin{array}{l}\text { No significant differences } \\
\text { between groups were found } \\
\text { on affect (pleasure }(z=-1.544 \text {, } \\
p=0.123) \text {, anxiety }(z=-0.086 \text {, } \\
p=0.932) \text { and interest }(z=-1.26 \text {, } \\
p=0.208) \text { ). Levels of adaptive } \\
\text { behaviour differed between } \\
\text { the groups, with the treatment } \\
\text { group demonstrating higher } \\
\text { levels of active }(z=-2.90 \text {, } \\
p=0.00) \text {, passive ( } z=-2.72 \text {, } \\
p=0.01) \text { and other engagement } \\
(z=-3.47, p=0.00 \text { ) and } \\
\text { the comparison group } \\
\text { demonstrating higher levels } \\
\text { of self-engagement }(z=-4.60 \text {, } \\
p=0.00)\end{array}$ & $\begin{array}{l}\text { HT-based activities } \\
\text { successfully facilitate } \\
\text { lower levels of self- } \\
\text { engaging behaviours } \\
\text { and engage groups } \\
\text { of dementia sufferers } \\
\text { who are often difficult } \\
\text { to engage in activities } \\
\text { that elicit high levels } \\
\text { of adaptive behaviour }\end{array}$ \\
\hline
\end{tabular}


Table 1 Continued

\begin{tabular}{ll}
$\begin{array}{l}\text { Author, date } \\
\text { and country }\end{array}$ & Study aims \\
\hline $\begin{array}{ll}\text { Van den Berg } \\
\text { et al, The }\end{array}$ & $\begin{array}{l}\text { To hypothesise } \\
\text { and test the stress- } \\
\text { Netherlands } \\
\text { relieving effects of } \\
\end{array}$ \\
& gardening
\end{tabular}

$\begin{array}{ll}\text { Netherlands } & \text { relieving effer } \\ & \text { gardening }\end{array}$

Garden type A

Age

Mean age 57.6 years Affect Schedule (PANAS)), saliva samples collected shortly after arrival at the experimental location, before/after the stressful task, halfway through and after experimental activity. PANAS assessed prior to/ after stressor and after experimental activity levels and self-reported (range 38-79) mood (Positive and Negative

\section{Key findings}

Study findings suggest that gardening has a positive impact on relief from acute stress. Both gardening and reading decreased cortisol levels during the recovery period, with significantly stronger decreases seen in the gardening group ( $\mathrm{F}$ $(1,11)=24.15, p<0.001$ vs. $F(1$, $13)=5.33, p<0.05)$. Postactivity, cortisol levels were marginally lower in the gardening group than in the reading group $(F(1$, $27)=3.21, p=0.08)$. A significant increase in positive mood was seen in the gardening group $(F(1,12)=4.91, p<0.05)$, but deteriorated by $4.3 \%$ in the reading group $(p=0.53)$. Postactivity positive mood was significantly higher in the gardening group than in the reading group $(F(1,28)=4.93$, $\mathrm{p}<0.05)$.

\begin{tabular}{|c|c|c|c|c|c|c|}
\hline $\begin{array}{l}\text { Gatto et al, } \\
\text { USA }^{43}\end{array}$ & $\begin{array}{l}\text { To explore the } \\
\text { effects of a novel } \\
\text { 12-week gardening, } \\
\text { nutrition and } \\
\text { cooking intervention } \\
\text { ('LA Sprouts') on } \\
\text { dietary intake, } \\
\text { obesity parameters } \\
\text { and metabolic } \\
\text { disease risk among } \\
\text { low-income, } \\
\text { primarily Hispanic/ } \\
\text { Latino youth in Los } \\
\text { Angeles }\end{array}$ & $\begin{array}{l}\text { Structured } \\
\text { gardening } \\
\text { programme }\end{array}$ & $\begin{array}{l}\text { Third, } \\
\text { fourth and } \\
\text { fifth grade } \\
\text { students } \\
\text { (age range } \\
8-11 \text { years) }\end{array}$ & $\begin{array}{l}\text { Dietary intake measured } \\
\text { via food frequency } \\
\text { questionnaire, } \\
\text { anthropometric measures } \\
\text { (body mass index, waist } \\
\text { circumference), body fat and } \\
\text { fasting blood samples }\end{array}$ & $\begin{array}{l}\text { Study findings indicate } \\
\text { that pupils participating in } \\
\text { LA sprouts had significant } \\
\text { reductions in body mass index } \\
z \text {-scores as compared with the } \\
\text { controls }(-0.1 \text { vs }-0.04, p=0.01) \text {. } \\
\text { Waist circumference in the LA } \\
\text { Sprouts group decreased more } \\
\text { than the control ( }-1.2 \text { vs } 0.1 \mathrm{~cm} \text { : } \\
\text { p } 0.001) \text {. Dietary fibre increased } \\
\text { with LA sprouts as compared } \\
\text { with the controls (+3.4\% vs } \\
-16.5 \% \text {; } p=0.04) \text {, however there } \\
\text { was no difference in the fruit } \\
\text { intake between the LA Sprouts } \\
\text { and control groups }\end{array}$ & $\begin{array}{l}\text { The findings are } \\
\text { positive and indicate } \\
\text { that LA Sprouts } \\
\text { can benefit pupils' } \\
\text { nutritional behaviours } \\
\text { and impact on body } \\
\text { mass index and waist } \\
\text { circumference, but } \\
\text { larger, longitudinal } \\
\text { studies are required }\end{array}$ \\
\hline $\begin{array}{l}\text { Kam et al, } \\
\text { China }^{110}\end{array}$ & $\begin{array}{l}\text { To examine HT } \\
\text { activity on reduced } \\
\text { stress, improved } \\
\text { quality of life and } \\
\text { work performance } \\
\text { for people with } \\
\text { psychiatric } \\
\text { disorders }\end{array}$ & $H T^{\star *}$ & $\begin{array}{l}\text { Mean age of } \\
44.3 \text { years } \\
(S D=11.6)\end{array}$ & $\begin{array}{l}\text { Well-being and quality of } \\
\text { life (Personal Well-being } \\
\text { Index (PWI-C)), mental state } \\
\text { and behaviour (Depression } \\
\text { Anxiety Stress Scale (DASS- } \\
\text { 21)), general functioning } \\
\text { (Work Behaviour Assessment } \\
\text { (WBA)), PWI-C and DASS-21 } \\
\text { measured before and after } \\
\text { intervention }\end{array}$ & $\begin{array}{l}\text { A significant positive impact } \\
\text { of the horticultural programme } \\
\text { was seen in DASS- } 21 \text { total } \\
\text { ( } p=0.01 \text { ), depression ( } p=0.04 \text { ), } \\
\text { anxiety ( } p=0.01 \text { ) and stress } \\
\text { ( } p=0.5 \text { ) subscales. No significant } \\
\text { differences were seen in change } \\
\text { of WBA and its subscales } \\
\text { ( } p \text { values range from } 0.08 \\
\text { to } 0.79 \text { ) and PWI ( } p=0.84 \text { ). } \\
\text { Qualitative evidence suggested } \\
\text { a positive impact on emotional, } \\
\text { occupational, social and } \\
\text { spiritual aspects }\end{array}$ & $\begin{array}{l}\mathrm{HT} \text { is effective in } \\
\text { reducing anxiety, } \\
\text { depression and } \\
\text { stress but no } \\
\text { difference was seen } \\
\text { on work behaviour } \\
\text { or quality of life }\end{array}$ \\
\hline $\begin{array}{l}\text { Bail et al } \\
\text { (2018) UK }\end{array}$ & $\begin{array}{l}\text { To assess a mentor } \\
\text { home-based } \\
\text { vegetable garden } \\
\text { as an intervention } \\
\text { to cancer survivors } \\
\text { to explicate health- } \\
\text { related outcomes }\end{array}$ & $\begin{array}{l}\text { Gardening } \\
\text { programme }\end{array}$ & $\begin{array}{l}\text { Adults }- \text { all } \\
\text { ages, mean } \\
\text { age of } 60 \\
\text { years }\end{array}$ & $\begin{array}{l}\text { Health-related outcomes } \\
\text { (secondary outcomes of } \\
\text { vegetable consumption, } \\
\text { physical activity, } \\
\text { performance and function, } \\
\text { HRQOL, anthropometrics } \\
\text { and biomarkers) veg } \\
\text { consumption, physical } \\
\text { activity, HRQOL, } \\
\text { Physical Performance, } \\
\text { Anthropometrics, biomarkers } \\
\text { such as toenail clippings } \\
\text { to measure chronic stress } \\
\text { levels }\end{array}$ & $\begin{array}{l}100 \% \text { satisfaction with the } \\
\text { programme. Statistically } \\
\text { significant improvements } \\
\text { with physical activities and } \\
\text { vegetable consumption. Positive } \\
\text { changes reported in the HRQOL } \\
\text { scores. Non-significant trends } \\
\text { noted in the body mass index } \\
\text { recordings. Overall, positive } \\
\text { changes were reported across } \\
\text { both groups, with a marked } \\
\text { improvement in the intervention } \\
\text { groups scores compared with } \\
\text { the controls. }\end{array}$ & $\begin{array}{l}\text { Home-based } \\
\text { mentoring } \\
\text { gardening } \\
\text { programme can } \\
\text { significantly } \\
\text { improve biometric } \\
\text { outcomes } \\
\text { and vegetable } \\
\text { consumption }\end{array}$ \\
\hline
\end{tabular}

Continued

Author conclusions

Gardening can promote relief from acute stress. Gardens can be used as a valuable resource to prevent disease and promote health 
Table 1 Continued

\begin{tabular}{|c|c|c|c|c|c|c|}
\hline $\begin{array}{l}\text { Author, date } \\
\text { and country }\end{array}$ & Study aims & Garden type & Age & Outcomes measured & Key findings & Author conclusions \\
\hline $\begin{array}{l}\text { Lai et al, } \\
\text { China } 65\end{array}$ & $\begin{array}{l}\text { To explicate the } \\
\text { impact of HT on } \\
\text { frail older nursing } \\
\text { home residents on } \\
\text { psychological well- } \\
\text { being }\end{array}$ & $\mathrm{HT}^{\star *}$ & $\begin{array}{l}\text { Frail older } \\
\text { adult and } \\
\text { prefrail }\end{array}$ & $\begin{array}{l}\text { Happiness was measured } \\
\text { using the subjective } \\
\text { happiness scale; frailty } \\
\text { was measured using the } \\
\text { five-item Fried Frailty Index; } \\
\text { depressive symptoms } \\
\text { were measured using the } \\
\text { Geriatric Depression Scale; } \\
\text { self-efficacy was measured } \\
\text { using the 10-item General } \\
\text { Self-Efficacy Scale; social } \\
\text { engagement measured using } \\
\text { the Social Engagement } \\
\text { Scale; social networks were } \\
\text { measured using Lubbens } \\
\text { Social Network Scale and } \\
\text { well-being was measured } \\
\text { using the Personal Well- } \\
\text { being Index }\end{array}$ & $\begin{array}{l}\text { Significant improvement in the } \\
\text { interaction time was observed } \\
\text { in the happiness scale in the } \\
\text { HT groups }(\beta=1.457, p=0.036) \text {. } \\
\text { No significant changes noted } \\
\text { in any of the other outcomes. } \\
\text { A later cluster analysis (follow- } \\
\text { up) indicated greater effects on } \\
\text { subjective happiness for the HT } \\
\text { group (mean difference }=6.23 \text {, } \\
\text { p<0.001) as compared with the } \\
\text { controls at baseline }\end{array}$ & $\begin{array}{l}\text { Frail and prefrail } \\
\text { older people living } \\
\text { in a nursing home } \\
\text { can benefit from HT } \\
\text { and can promote } \\
\text { subjective happiness }\end{array}$ \\
\hline
\end{tabular}

$\mathrm{HT}^{\star \star}$, horticultural therapy.

gardens on mental health (36\%). General well-being represented $32 \%$ of the total outcomes reported. There was an even split between those papers reporting on specific physical outcomes (14\%) and those reporting on nutrition as an outcome (18\%). The heterogeneous outcomes may explain the paucity of meta-analyses (3.7\%).

\section{Development of the logic models}

A secondary objective was to use this evidence to build evidence-based logic models to guide health strategy decision making about gardens and gardening as a nonmedical, social prescription. Logic models illustrate causal relationships between service inputs, resultant activities, outputs and goals, emphasising the contributory factors to successful programmes. ${ }^{101}$ The structure and organisation of logic models enable the results from scoping reviews and systematic reviews to delineate complex interventions, such as those without specific, controlled parameters thus enabling greater insight into the interactions between the intervention, in this case gardens and gardening, and the multiple outcomes. ${ }^{102}$ Logic models can represent causal processes and encapsulate complex interventions and illustrate heterogeneous outcomes. ${ }^{18}$ Hence, logic models provide an evidence-based tool that can support policy makers, healthcare strategists and/or primary healthcare clinician's decisions about commissioning non-medical approaches through social prescribing.

\section{Logic model: evidence evaluating the impact of gardens on mental health}

There were $29(36 \%)$ studies that focused on the impact of gardening on mental health. We set parameters for mental well-being to include four main areas of interest: psychological well-being, depression, anxiety and mental status. In the latter, we resolved that mental status included pathological disorders such as dementia, schizophrenia, bipolar and other chronic LTCs. Some categories overlapped, for example, papers with a focus on psychological well-being often captured outcomes relating to depression making the creation of distinct categories problematic. Commonly reported data collection methods included validated tools such as the Warwick-Edinburgh Mental Well-being Scale ${ }^{103}$ or New Economic Foundation's Five Ways to Well-being, ${ }^{104}$ which offer observational subjective data as opposed to direct causality. Evidence from our review indicated a range of benefits that gardening had on diverse populations. Typically, gardening enabled greater social interaction with others $^{92}$ and improved physical activity, ${ }^{100}$ thus improving overall mental well-being, ${ }^{32}$ reducing depression ${ }^{76}$ and anxiety. ${ }^{59}$

A significant percentage of papers $(36 \%)$ focused on mental health, and of these, the majority $(57 \%)$ used experimental or quasi-experimental designs. The causal relationships illustrated in our first logic model highlights the range of garden activities that contributed to an improvement in mental health (see figure 2). These papers typically reported that gardens and gardening augmented physical activities resulting in improved physiological outcomes such as reduced cortisol levels 323596 and saliva amylase levels. ${ }^{96}$ Additionally, the logic model graphic enables visual representation of how mental health was improved through enhancing sociological outcomes leading to reduced socialisation through improved social networks.

\section{Logic model: evidence evaluating the impact of gardens on general well-being}

In determining a parameter for well-being, we used the study by Dodge et al ${ }^{105}$ who asserts that 'stable 'well-being' is when individuals have the psychological, social and physical resources they need to meet a particular psychological, social and/or physical challenge'. Hence, a range of well-being 
Table 2 Evidence summary: systematic reviews

\begin{tabular}{|c|c|c|c|c|c|}
\hline $\begin{array}{l}\text { Author, date } \\
\text { and country }\end{array}$ & Aims & $\begin{array}{l}\text { Type of } \\
\text { gardens }\end{array}$ & Outcomes measured & Key findings & $\begin{array}{l}\text { Authors' } \\
\text { conclusions }\end{array}$ \\
\hline $\begin{array}{l}\text { Cipriani et al, } \\
\text { USA }{ }^{32}\end{array}$ & $\begin{array}{l}\text { To conduct a } \\
\text { systematic review } \\
\text { on the benefits } \\
\text { of HT on persons } \\
\text { with mental health } \\
\text { conditions who } \\
\text { are receiving } \\
\text { services in either } \\
\text { inpatient settings } \\
\text { or outpatient } \\
\text { community-based } \\
\text { settings }\end{array}$ & $H T^{\star *}$ & $\begin{array}{l}\text { Outcome measures reported in included } \\
\text { studies: affect, agitation, behaviour/ } \\
\text { engagement, cognitive functioning, } \\
\text { interpersonal relationship, physical well- } \\
\text { being, psychiatric symptomatology, } \\
\text { psychological/mental well-being, } \\
\text { quality of life, self-esteem, sleep, social } \\
\text { behaviour, stress and coping, volition, } \\
\text { work behaviour. Tools reported in } \\
\text { included studies: Affect Balance Scale, } \\
\text { Test for Severe Impairment, Quality } \\
\text { of Life Enjoyment and Satisfaction } \\
\text { Questionnaire Short Form (Q-LES-Q- } \\
\text { SF), Alcohol Craving Questionnaire, } \\
\text { Post-traumatic Stress Disorder } \\
\text { Checklist Civilian Version, Centre for } \\
\text { Epidemiologic Studies Depression } \\
\text { Scale (CES-D), cortisol levels, modified } \\
\text { DCM (dementia care mapping) Scale, } \\
\text { home-made assessment for behaviour } \\
\text { and a modified DCM, interviews, The } \\
\text { Bradford Well-Being Profile, Mini- } \\
\text { Mental State Examination, Apparent } \\
\text { Affect Rating Scale, Menorah Park } \\
\text { Engagement Scale, Chinese version of } \\
\text { Depression Anxiety Stress Scale 21, } \\
\text { Work Behaviour Assessment, Chinese } \\
\text { version of Personal Well-being Index, } \\
\text { sleep diary, Modified Cohen-Mansfield } \\
\text { Agitation Inventory, Revised Hasegawa } \\
\text { Dementia Scale, Cohen-Mansfield } \\
\text { Agitation Inventory, Physical and Mental } \\
\text { Impairment Functional Evaluation, Multi- } \\
\text { focus Assessment Scale for the Frail } \\
\text { Elderly, Participation Index (Caplovitz) } \\
\text { and Participation Index (Phillips), } \\
\text { Volitional Questionnaire, Relationship } \\
\text { Change Scale, Self-Esteem Scale, Social } \\
\text { Behaviour Scale, Symptom Checklist } \\
\text { 90 Revision, Evaluation of Horticultural } \\
\text { Activity }\end{array}$ & $\begin{array}{l}14 \text { studies were included in the } \\
\text { review. Study designs include } \\
5 \text { randomised controlled trial, } \\
6 \text { cohort, } 2 \text { before and after, } 1 \\
\text { cross-sectional. } 11 / 14 \text { studies } \\
\text { found statistically significant } \\
\text { findings in support of HT for at } \\
\text { least one dependent variable. } \\
\text { Studies were conducted in a } \\
\text { variety of settings and mental } \\
\text { health conditions. Limitations } \\
\text { of the studies include, a lack } \\
\text { of detail on the interventions in } \\
\text { the included studies would limit } \\
\text { reproducibility and a lack of } \\
\text { information on the reliability and } \\
\text { validity of outcome measures }\end{array}$ & $\begin{array}{l}\text { Moderate } \\
\text { evidence exists } \\
\text { that horticultural } \\
\text { therapy can improve } \\
\text { client factors and } \\
\text { performance skills }\end{array}$ \\
\hline
\end{tabular}

Continued 
Table 2 Continued

\begin{tabular}{|c|c|c|c|c|c|}
\hline $\begin{array}{l}\text { Author, date } \\
\text { and country }\end{array}$ & Aims & $\begin{array}{l}\text { Type of } \\
\text { gardens }\end{array}$ & Outcomes measured & Key findings & $\begin{array}{l}\text { Authors' } \\
\text { conclusions }\end{array}$ \\
\hline Ohly et al, UK ${ }^{86}$ & $\begin{array}{l}\text { To review whether } \\
\text { school gardens } \\
\text { benefited health } \\
\text { and well-being } \\
\text { of pupils and } \\
\text { understand factors } \\
\text { that enabled or } \\
\text { challenged the } \\
\text { success }\end{array}$ & $\begin{array}{l}\text { School } \\
\text { gardening }\end{array}$ & $\begin{array}{l}\text { Studies were included if they reported } \\
\text { quantitative or qualitative health and } \\
\text { well-being outcomes. Outcomes } \\
\text { reported include fruit and vegetable } \\
\text { intake (structured dietary assessment } \\
\text { method, Child and Diet Evaluation Tool } \\
\text { (CADET), lunchtime observations, parent } \\
\text { questionnaire, } 24 \text { hours recall workbooks, } \\
\text { parent survey, Garden Vegetables } \\
\text { Frequency Questionnaire, taste test); } \\
\text { nutrients intake (CADET, 24-hour urine } \\
\text { samples; flame photometry, Block Food } \\
\text { Screener, Parent Questionnaire, 24- } \\
\text { hour recall workbooks); physical (waist } \\
\text { circumference, body mass index, and } \\
\text { systolic and diastolic blood pressures, } \\
\text { urinary sodium, total fat (\%), GEMS } \\
\text { Activity Questionnaire, Accelerometery, } \\
\text { well-being (KIDSCREEN-10, Teacher } \\
\text { Questionnaire, Quality of school life } \\
\text { instrument, Youth Life Skills Inventory, } \\
\text { Self-Report of Personality Scale for } \\
\text { children and adolescents) }\end{array}$ & 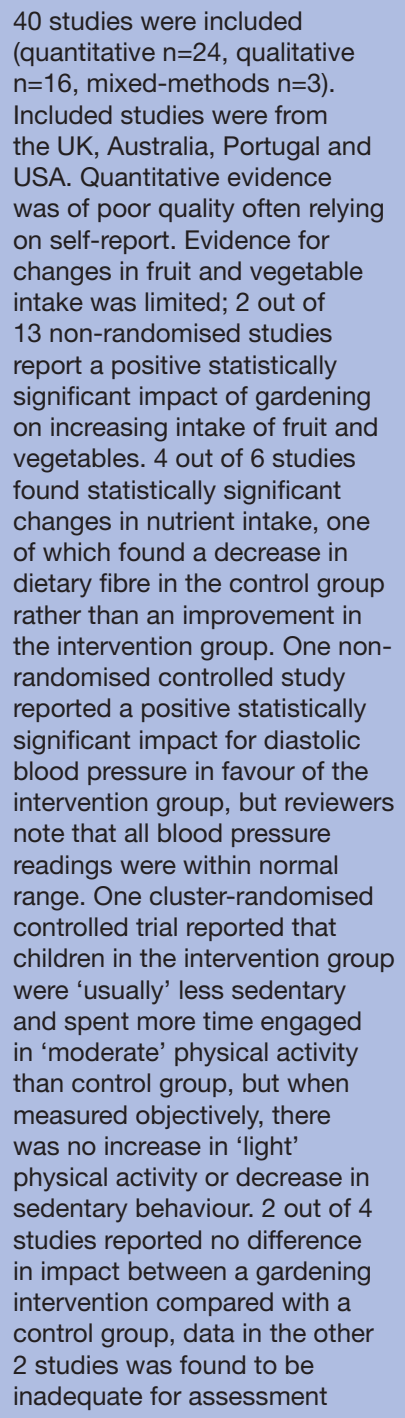 & $\begin{array}{l}\text { There is limited } \\
\text { quantitative } \\
\text { evidence for } \\
\text { the impacts of } \\
\text { school gardens. } \\
\text { Qualitative } \\
\text { evidence suggests } \\
\text { that participants } \\
\text { of gardening } \\
\text { programmes may } \\
\text { experience or } \\
\text { perceive a range } \\
\text { of health/well- } \\
\text { being outcomes. } \\
\text { There are few } \\
\text { studies that } \\
\text { have used logic } \\
\text { models to illustrate } \\
\text { the impact of } \\
\text { school gardens } \\
\text { as complex } \\
\text { interventions }\end{array}$ \\
\hline$\underset{94}{\text { Stern, Australia }}$ & $\begin{array}{l}\text { To locate and } \\
\text { synthesise best } \\
\text { evidence about } \\
\text { impact of physical } \\
\text { activities on people } \\
\text { with dementia }\end{array}$ & Gardening & $\begin{array}{l}\text { The Diagnostic Statistical Manual of } \\
\text { Mental Disorders was used to classify } \\
\text { the absence or presence of dementia. } \\
\text { Mental examination tools such as the } \\
\text { Mini-Mental State Examination and } \\
\text { activities of daily living }\end{array}$ & $\begin{array}{l}\text { 9/17 studies included in the } \\
\text { systematic review looked at } \\
\text { gardening as an intervention. } \\
\text { Positive impacts of gardening } \\
\text { were reported by one case- } \\
\text { control study on a beneficial } \\
\text { association with a reduction } \\
\text { in the chance of developing } \\
\text { Alzheimer's disease. Two cohort } \\
\text { studies found that gardening } \\
\text { was significantly associated } \\
\text { with a reduced risk of dementia } \\
\text { (RR=0.53, } 95 \% \text { Cl } 0.28 \text { to } 0.99 ; \\
\text { HR, } 0.64,95 \% \mathrm{Cl} 0.50 \text { to } 0.83 \text { ). } \\
\text { Another cohort reported that } \\
\text { exposure to gardening over at } \\
\text { least } 10 \text { years may be associated } \\
\text { with a reduced risk of developing } \\
\text { Alzheimer's disease }\end{array}$ & $\begin{array}{l}\text { While the evidence } \\
\text { is equivocal } \\
\text { on whether } \\
\text { participation in } \\
\text { physical activities } \\
\text { is protective } \\
\text { against onset } \\
\text { of dementia, } \\
\text { gardening appears } \\
\text { more beneficial } \\
\text { than other types } \\
\text { of activities. Data } \\
\text { were extracted } \\
\text { only for gardening }\end{array}$ \\
\hline
\end{tabular}

Continued 
Table 2 Continued

\begin{tabular}{|c|c|c|c|c|c|}
\hline $\begin{array}{l}\text { Author, date } \\
\text { and country }\end{array}$ & Aims & $\begin{array}{l}\text { Type of } \\
\text { gardens }\end{array}$ & Outcomes measured & Key findings & $\begin{array}{l}\text { Authors' } \\
\text { conclusions }\end{array}$ \\
\hline $\begin{array}{l}\text { Wang et al, } \\
\text { USA }^{97}\end{array}$ & $\begin{array}{l}\text { Systemic review } \\
\text { evidence for } \\
\text { beneficial effects of } \\
\text { gardening on older } \\
\text { adults }\end{array}$ & Gardening & $\begin{array}{l}\text { Range of outcome measures, as } \\
\text { authors sought to locate papers based } \\
\text { on methodological approach rather } \\
\text { than outcomes. Hence, outcomes } \\
\text { were mixed and included Mini-Mental } \\
\text { State Examination, Apparent Affect } \\
\text { Rating Scales, nutrition Menorah Park } \\
\text { Engagement Scale, Life Satisfaction } \\
\text { Inventory, Stress tests, Perceived health } \\
\text { and Well-Being Scales, self-reported } \\
\text { pain, SF36, hand function, Self-Rated } \\
\text { Health and Happiness Scale, Pearlins ad } \\
\text { Schoolers Mastery Scale, sleep diaries, } \\
\text { Modified Cohen-Mansfiled Agitation } \\
\text { Inventory and Revised Hasegave } \\
\text { Dementia Scale }\end{array}$ & $\begin{array}{l}22 \text { articles were reviewed } \\
\text { (adults). Through various } \\
\text { research designs (quantitative } \\
\text { and qualitative) and } \\
\text { measurements used, the results } \\
\text { reveal that gardening can } \\
\text { be an activity that promotes } \\
\text { overall health and quality of } \\
\text { life, physical strength, fitness } \\
\text { and flexibility, cognitive } \\
\text { ability, and socialisation. The } \\
\text { implementation of various } \\
\text { aspects of gardening as health- } \\
\text { promoting activities transcend } \\
\text { contexts of practice and } \\
\text { disciplines and can be used in } \\
\text { urban and rural communities } \\
\text { as both individual and group } \\
\text { activities }\end{array}$ & $\begin{array}{l}\text { The authors } \\
\text { conclude that the } \\
\text { literature reported } \\
\text { variable findings, and } \\
\text { while most of these } \\
\text { were positive, the } \\
\text { majority were at an } \\
\text { exploratory stage. } \\
\text { The evidence base } \\
\text { provides an intriguing } \\
\text { foundation for further } \\
\text { research. Gardening } \\
\text { has positive effects } \\
\text { on older adults } \\
\text { and help improve } \\
\text { engagement and } \\
\text { activity participation } \\
\text { for people with } \\
\text { dementia }\end{array}$ \\
\hline $\begin{array}{l}\text { Whear et al, } \\
\text { UK }^{98}\end{array}$ & $\begin{array}{l}\text { To examine the } \\
\text { impact of gardens } \\
\text { and outdoor spaces } \\
\text { on the mental } \\
\text { and physical well- } \\
\text { being of people } \\
\text { with dementia } \\
\text { who are resident } \\
\text { in care homes and } \\
\text { understand the } \\
\text { views of people } \\
\text { with dementia, their } \\
\text { carers, and care } \\
\text { home staff on the } \\
\text { value of gardens } \\
\text { and outdoor } \\
\text { spaces. }\end{array}$ & $\begin{array}{l}\text { Garden } \\
\text { visiting }\end{array}$ & $\begin{array}{l}\text { Included studies had to report on } \\
\text { agitation, number of falls, aggression, } \\
\text { physical activity, cognitive functioning, } \\
\text { or quality of life (quantitative) or report } \\
\text { on the views of people with dementia } \\
\text { who were resident in care homes, care } \\
\text { home staff, carers, and families on the } \\
\text { use of gardens and outdoor spaces } \\
\text { (qualitative). (Tools reported in included } \\
\text { studies-Agitation: Cohen-Mansfield } \\
\text { Agitation Inventory (CMAl); Emotional } \\
\text { outcomes: Affect Rating Scale) }\end{array}$ & $\begin{array}{l}\text { A total of } 17 \text { studies were } \\
\text { included ( } 9 \text { quantitative, } 7 \\
\text { qualitative and } 1 \text { mixed- } \\
\text { methods). Quantitative designs } \\
\text { included } 6 \text { prepost studies, } 2 \\
\text { randomised controlled trials, } 1 \\
\text { prospective cohort, } 1 \text { cross-over } \\
\text { trial. Quantitative designs were } \\
\text { of poor quality but suggest a } \\
\text { beneficial effect associated with } \\
\text { garden use on reduced levels of } \\
\text { agitation. There was insufficient } \\
\text { evidence from quantitative } \\
\text { studies generalising the findings } \\
\text { on other aspects of physical } \\
\text { and mental well-being. Evidence } \\
\text { on the impact of HT was } \\
\text { inconclusive }\end{array}$ & $\begin{array}{l}\text { Garden use } \\
\text { provides promising } \\
\text { impacts on levels } \\
\text { of agitation in care } \\
\text { home residents } \\
\text { with dementia } \\
\text { who spend time in } \\
\text { a garden. Future } \\
\text { research should } \\
\text { focus on using } \\
\text { comparative } \\
\text { outcome measures }\end{array}$ \\
\hline $\begin{array}{l}\text { Savoie-Roskos } \\
\text { et al, USA }\end{array}$ & $\begin{array}{l}\text { To identify the } \\
\text { effectiveness } \\
\text { of gardening } \\
\text { interventions } \\
\text { that have been } \\
\text { implemented } \\
\text { to increase fruit } \\
\text { and vegetables } \\
\text { consumption } \\
\text { among children }\end{array}$ & Gardening & $\begin{array}{l}\text { Fruit and vegetable consumption among } \\
\text { children aged } 2-15 \text { years before and } \\
\text { after implementation of a gardening } \\
\text { intervention in a school, community or } \\
\text { after-school setting }\end{array}$ & $\begin{array}{l}\text { There were } 14 \text { papers located } \\
\text { and included in the review. A } \\
\text { total of } 10 \text { articles reported } \\
\text { statistically significant increases } \\
\text { in fruit or vegetable consumption } \\
\text { for those who participated in } \\
\text { the gardening intervention. } \\
\text { The papers located varied in } \\
\text { methodologies and many had } \\
\text { small sample sizes and relied on } \\
\text { the use of convenience samples, } \\
\text { and self-reported measurements } \\
\text { of F/V consumption. While the } \\
\text { effects are small, the evidence } \\
\text { reports a positive benefit on } \\
\text { the consumption of F/V in the } \\
\text { children who participated in } \\
\text { gardening }\end{array}$ & $\begin{array}{l}\text { The evidence } \\
\text { suggests a modest } \\
\text { but positive influence } \\
\text { of gardens on F/ } \\
\text { intake of children }\end{array}$ \\
\hline $\begin{array}{l}\text { Annerstedt et } \\
\text { al, Sweden }\end{array}$ & $\begin{array}{l}\text { To systematically } \\
\text { review the literature } \\
\text { regarding effects } \\
\text { of nature-assisted } \\
\text { therapy (NAT), for } \\
\text { patients with well- } \\
\text { defined diseases, } \\
\text { as a treatment } \\
\text { option either alone, } \\
\text { or together with } \\
\text { other evidence- } \\
\text { based treatment } \\
\text { options }\end{array}$ & Gardens & $\begin{array}{l}\text { Studies were included if they reported } \\
\text { systematic review and meta-analyses } \\
\text { of randomised controlled trials; } \\
\text { randomised controlled trial's; non- } \\
\text { randomised intervention studies, } \\
\text { observational studies and qualitative } \\
\text { studies. Nature-based, nature-assisted, } \\
\text { gardening, horticulture, sociohorticulture, } \\
\text { ecotherapy were included. A range of } \\
\text { psychological, intellectual, social and } \\
\text { physiological outcomes were included }\end{array}$ & $\begin{array}{l}38 \text { papers ( } 3 \text { systematic } \\
\text { reviews/meta-analysis, } 6 \\
\text { randomised controlled trials, } \\
12 \text { non-randomised trials, } 14 \\
\text { observational, } 4 \text { qualitative) } \\
\text { published between May } 1980 \\
\text { and } 2009 \text { were included. The } \\
\text { authors report } 13 \text { significant } \\
\text { improvements for psychological } \\
\text { goals, } 6 \text { for social goals, } 4 \\
\text { for physical goals and } 2 \text { for } \\
\text { intellectual goals }\end{array}$ & $\begin{array}{l}\text { The authors } \\
\text { conclude that the } \\
\text { evidence base } \\
\text { reports a small, but } \\
\text { reliable resource } \\
\text { that highlights the } \\
\text { benefits of NAT as an } \\
\text { approach to promote } \\
\text { health. Future } \\
\text { studies should be } \\
\text { adequately powered } \\
\text { with clearly defined } \\
\text { definitions }\end{array}$ \\
\hline
\end{tabular}


Table 2 Continued

\begin{tabular}{|c|c|c|c|c|c|}
\hline $\begin{array}{l}\text { Author, date } \\
\text { and country }\end{array}$ & Aims & $\begin{array}{l}\text { Type of } \\
\text { gardens }\end{array}$ & Outcomes measured & Key findings & $\begin{array}{l}\text { Authors' } \\
\text { conclusions }\end{array}$ \\
\hline $\begin{array}{l}\text { Kamioka et al, } \\
\text { Japan }^{60}\end{array}$ & $\begin{array}{l}\text { To summarise } \\
\text { evidence of } \\
\text { randomised } \\
\text { controlled trials } \\
\text { on the effects of } \\
\text { horticultural therapy }\end{array}$ & $H \mathrm{~T}^{\star \star}$ & $\begin{array}{l}\text { Inclusion criteria looked for all cure and } \\
\text { rehabilitation effects in accordance } \\
\text { with the International Classification } \\
\text { of Diseases-10. Included studies } \\
\text { reported on; Affect (the Apparent Affect } \\
\text { Rating Scale) Engagement (Menorah } \\
\text { Park Engagement Scale) Chinese } \\
\text { version of Depression Anxiety Stress } \\
\text { Scale } 21 \text { (DASS-21) Work Behaviour } \\
\text { Assessment (WBA) Chinese version of } \\
\text { the Personal Well-being Index (PWI-C) } \\
\text { Life Satisfaction Index-A Form, Revised } \\
\text { UCLA Loneliness Scale The Lubben } \\
\text { Social Network Scale Self-esteem } \\
\text { Scale, Powerlessness Beck Depression } \\
\text { Inventory (BDI) Neurobehavioral } \\
\text { Cognitive Status Examination (NCSE), } \\
\text { motor-free visual perception test (MVPT) } \\
\text { and functional independence measure } \\
\text { (FIM) }\end{array}$ & $\begin{array}{l}4 \text { studies met all inclusion } \\
\text { criteria. All studies showed } \\
\text { significant effectiveness in one } \\
\text { or more outcomes for mental } \\
\text { health and behaviour. No studies } \\
\text { report cost-effectiveness. } \\
\text { Methodological quality of the } \\
\text { randomised controlled trials } \\
\text { was low }\end{array}$ & $\begin{array}{l}\text { People with mental } \\
\text { and behavioural } \\
\text { disorders such } \\
\text { as dementia, } \\
\text { schizophrenia, } \\
\text { depression and } \\
\text { terminal care for } \\
\text { cancer, may benefit } \\
\text { from HT, however the } \\
\text { evidence supporting } \\
\text { this is of low quality }\end{array}$ \\
\hline $\begin{array}{l}\text { Masset et al, } \\
\text { UK }^{75}\end{array}$ & $\begin{array}{l}\text { To assess the } \\
\text { effectiveness } \\
\text { of agricultural } \\
\text { interventions } \\
\text { in improving } \\
\text { the nutritional } \\
\text { status of children } \\
\text { in developing } \\
\text { countries }\end{array}$ & $\begin{array}{l}\text { Range } \\
\text { for review } \\
\text { including } \\
\text { gardens }\end{array}$ & $\begin{array}{l}\text { Dietary diversity, micronutrient } \\
\text { intake, prevalence of undernutrition, } \\
\text { participation and household income. } \\
\text { Studies were included if they were cross- } \\
\text { sectional and longitudinal project-control } \\
\text { comparisons and randomised field trials } \\
\text { and studies that compared participants } \\
\text { and non-participants over a single cross- } \\
\text { section }\end{array}$ & $\begin{array}{l}15 \text { studies assessed the } \\
\text { effectiveness of home gardens } \\
\text { (1 randomised controlled trial, } \\
\text { others longitudinal comparison } \\
\text { and cross-sectional studies). } \\
\text { A positive impact of home } \\
\text { gardens was found on increased } \\
\text { consumption of fruit and } \\
\text { vegetables. No evidence of } \\
\text { impact was found on iron intake } \\
\text { in children. Some evidence of } \\
\text { impact was found on improved } \\
\text { intake of vitamin A among } \\
\text { children <5 years (mean } \\
\text { difference } 2.4 \mu \text { gldL, } 95 \% \text { Cl } 1.67 \\
\text { to } 3.16 \text { ). Data for overall effects } \\
\text { of garden interventions on } \\
\text { children's nutritional status not } \\
\text { reported separately from other } \\
\text { interventions. Methodological } \\
\text { quality of included studies was } \\
\text { poor }\end{array}$ & $\begin{array}{l}\text { The review } \\
\text { authors concluded } \\
\text { that there was } \\
\text { limited evidence } \\
\text { of the impact } \\
\text { of agricultural } \\
\text { interventions on } \\
\text { the nutritional } \\
\text { status of children. } \\
\text { The authors } \\
\text { were unable } \\
\text { to answer the } \\
\text { systematic review } \\
\text { question with any } \\
\text { confidence due to } \\
\text { the methodological } \\
\text { weaknesses of the } \\
\text { studies }\end{array}$ \\
\hline $\begin{array}{l}\text { Garcia et al, } \\
\text { Brazil }^{42}\end{array}$ & $\begin{array}{l}\text { Systematic review } \\
\text { to explore the } \\
\text { impact of urban } \\
\text { gardens on use of } \\
\text { healthy food }\end{array}$ & $\begin{array}{l}\text { Community } \\
\text { gardening }\end{array}$ & $\begin{array}{l}\text { Key nutrition-related outcomes; } \\
\text { participation in urban gardens, food } \\
\text { security, healthy food practices, increase } \\
\text { in intake of fruit and vegetables, healthy } \\
\text { diet and improved family nutrition. } \\
\text { Impact on healthy food beliefs, healthy } \\
\text { food access, reduction in food costs, } \\
\text { greater interest in cooking and meal } \\
\text { planning }\end{array}$ & $\begin{array}{l}24 \text { studies were located. The } \\
\text { studies were heterogeneous } \\
\text { and included methodological } \\
\text { flaws. People who participated } \\
\text { in community gardens had } \\
\text { improved healthy diet intake, } \\
\text { shared food and valued healthy } \\
\text { food. People who participate in } \\
\text { gardens have an increased fruit } \\
\text { and vegetable intake, improved } \\
\text { access to health foods through } \\
\text { harvest sharing and improved } \\
\text { family diet }\end{array}$ & $\begin{array}{l}\text { Community gardens } \\
\text { can have a positive } \\
\text { impact on food } \\
\text { beliefs, knowledge } \\
\text { and practices. } \\
\text { Longer-term studies } \\
\text { with more robust } \\
\text { methodological } \\
\text { frameworks are } \\
\text { needed to verify } \\
\text { the benefits of } \\
\text { community gardens } \\
\text { on nutrition and diet }\end{array}$ \\
\hline $\begin{array}{l}\text { Kunpeuk et al, } \\
\text { Thailand }^{64}\end{array}$ & $\begin{array}{l}\text { Systematic } \\
\text { review and meta } \\
\text { analysis to explore } \\
\text { association } \\
\text { between community } \\
\text { gardening, nutrition } \\
\text { and physical health } \\
\text { in adults }\end{array}$ & $\begin{array}{l}\text { Community } \\
\text { gardening }\end{array}$ & $\begin{array}{l}\text { Diverse measurement units, but body } \\
\text { mass index only was pooled to enable } \\
\text { meta analysis }\end{array}$ & $\begin{array}{l}19 \text { articles were included in the } \\
\text { review. } 14 \text { cross-sectional, } 1 \\
\text { case-control and four quasi- } \\
\text { experimental. Results suggest } \\
\text { a modest positive impact of } \\
\text { gardens on body mass index } \\
\text { reduction. A greater pooled } \\
\text { effect size was reported for the } \\
\text { subgroup analysis of the quasi- } \\
\text { experimental and case-control } \\
\text { studies }\end{array}$ & $\begin{array}{l}\text { Gardens reduced } \\
\text { body mass index and } \\
\text { should be integrated } \\
\text { into health policy }\end{array}$ \\
\hline
\end{tabular}

Continued 
Table 2 Continued

\begin{tabular}{|c|c|c|c|c|c|}
\hline $\begin{array}{l}\text { Author, date } \\
\text { and country }\end{array}$ & Aims & $\begin{array}{l}\text { Type of } \\
\text { gardens }\end{array}$ & Outcomes measured & Key findings & $\begin{array}{l}\text { Authors' } \\
\text { conclusions }\end{array}$ \\
\hline $\begin{array}{l}\text { Nicholas et al, } \\
\text { Singapore }\end{array}$ & $\begin{array}{l}\text { To assess whether } \\
\text { HT was beneficial } \\
\text { for older people }\end{array}$ & $H T^{* *}$ & $\begin{array}{l}\text { Psychosocial, QOL, SF36, Ryffs Scales } \\
\text { of Psychological Wellbeing. Subjective } \\
\text { Happiness scale, Personal Wellbeing } \\
\text { Index, life satisfaction, dementia QOL }\end{array}$ & $\begin{array}{l}20 \text { articles were included } \\
\text { in the systematic review. } 6 \\
\text { experimental studies of which } \\
4 \text { were randomised controlled } \\
\text { trials. Other papers were quasi- } \\
\text { experimental. Most studies } \\
\text { reported significant effects of HT } \\
\text { on a range of outcomes although } \\
\text { there were mixed results on } \\
\text { the effect of HT on function. } \\
\text { Significant associations were } \\
\text { reported on agitation, mood and } \\
\text { engagement for people with } \\
\text { dementia }\end{array}$ & $\begin{array}{l}\text { The evidence for } \\
\text { HT is promising, } \\
\text { but more robust } \\
\text { evidence is required } \\
\text { to draw firm } \\
\text { conclusions }\end{array}$ \\
\hline
\end{tabular}

FN, fruit and vegetables; GEMS, Girls health Enrichment Multi-site Studies (GEMS) research team; HRQOL, Health Related Quality of Life ; HT ${ }^{* *}$, horticultural therapy; QOL, Quality of Life; SF36, Health Survey Questionnaire (SF-36); UCLA, Loneliness Scale.

indicators were reported that relate to both mental and physical well-being outcomes. A total of $26(32 \%)$ papers reported general well-being and typically focused on positive health; examples are 78100 social health, 2630324748 subjective well-being ${ }^{54} 94$ and/or quality of life. ${ }^{35} 38777998$ Typical LTCs studied included chronic lung disease $^{27}$ diabetes, hypertension and kidney disease. ${ }^{70}$ Outcomes that measured impact of gardens on nutrition were broad and included dietary changes, and increase in fruit and vegetable intake. There were 13 studies that explicated the impact of gardens and gardening on nutritional intake. ${ }^{29} 3142515458607581869698$ Key outcomes used as predictors for nutritional impact included validated scales for well-being, emotional health, mental health and physiological indicators. Overall, the findings report that the gardening interventions have a positive impact $(81 \%)$ on nutritional intake of fruit and vegetables and a range of physiological outcomes and general well-being.

The second logic model (see figure 3 ) provides an illustration of how gardens can benefit general well-being. The range of garden types located in the scoping review influenced activities that led to improved well-being outputs for adults, children and older people. Several positive

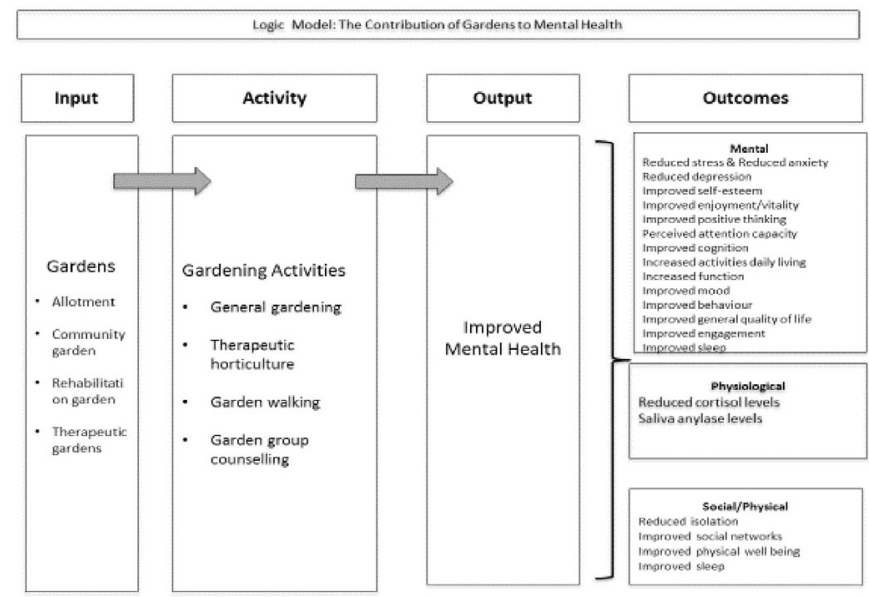

Figure 2 Logic model: mental health. outcomes were reported including social: involving skills, behaviours and networks; general mental wellbeing, such as stress reduction, ${ }^{35} 94$ reduced anxiety and depression. ${ }^{28}{ }^{60}{ }^{65}$ As with the mental health logic model, the graphic illustration enables visual representation of the overlap between the mental, physical, social and emotional outcomes. Thus, papers that reported impact on general well-being also included outcome measures that indicated increased physical activity resulting in reduced body mass index ${ }^{43}$ and healthier blood glucose levels, ${ }^{43}$ and general well-being that benefited community growth, ${ }^{66}$ social interaction ${ }^{6268}$ and quality of life. ${ }^{446676}$

These evidence-based logic models report the diversity of gardens and gardening interventions and subsequent benefits on a range of populations that may typically live with LTCs. The resultant outcomes reported provide confidence for clinicians considering gardens or gardening as a social prescription for a range of populations.

\section{DISCUSSION}

The increasing interest in social prescribing as a nonmedical approach, has gained international attention. ${ }^{106}$

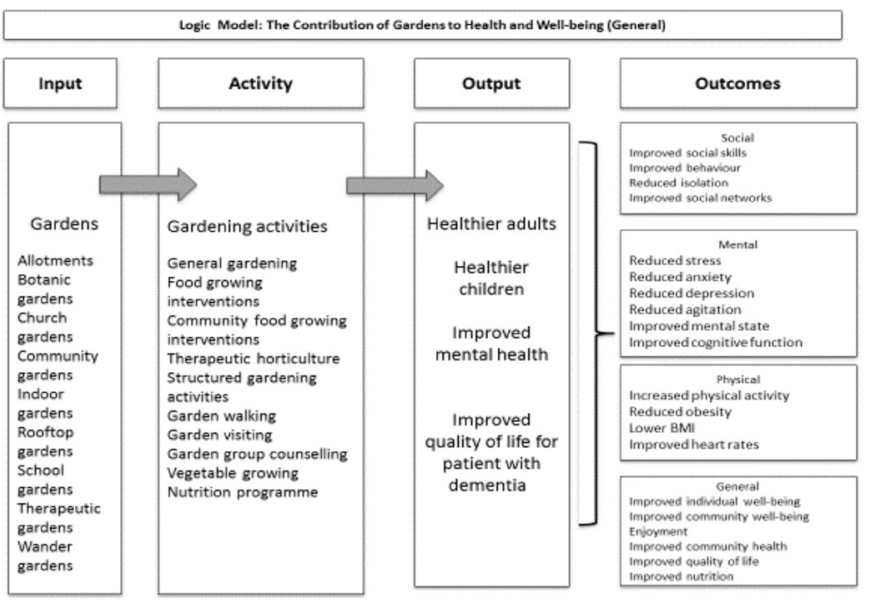

Figure 3 Logic model: well-being. 
Salutogenesis influences the question 'what makes people healthy?' rather than, 'how do we treat disease?'. Well-being is increasingly promoted through contemporary public health strategies to help reduce LTCs. ${ }^{107}$ Although research explicating the impact of gardens and gardening may be inhibited by the broad construct, the paradox here, suggests that it is the range offered that instigates the salutogenic response, ultimately impacting on the wider social determinants of health and benefiting diverse populations. Our findings indicate that diverse populations with LTCs could benefit from gardens and gardening as a salutogenic, social prescription and is the first to use a robust scoping review using a systematic approach to highlight these benefits.

Typically, gardening can help improve physiological outcomes associated with LTCs such as blood glucose levels, cortisol levels, HRV, blood lipids and salivary stress cortisol. Similar findings were identified by Nicklett $e t$ $a l^{84}$ and Ohly et $a l^{86}$ who reported positive physiological outcome measures on a range of biometrics including urinalysis, total fat, body mass index and systolic/diastolic blood pressure as outcomes. These findings, coupled with this review, demonstrate positive outcomes for a range of population needs including those living with obesity, diabetes, cardiovascular disease and other LTCs. The well-being of an individual is fundamental to health and is predicated on the social progression and quality of life, typically influenced by positive physical and mental health. Similar to Bragg et $a b^{30}$ our review identified that gardens and subsequent activities can help improve mental health. Bragg et $a l^{30}$ suggest that growing food can help combat stress and reduce associated depression. Likewise, Kam et a $\tilde{l}^{9}$ report positive emotional and social improvements for those who participated in a gardening programme. The benefits of gardening on mental health outcomes also extends to other LTCs known to influence frequent attendance to Accident \& Emergency (A\&E,) front-line health providers or GPs. ${ }^{108}$

Our scoping review has implications for researchers seeking to explicate the impact of nature-based solutions on populations. There is a predilection for the use of quasi-experimental pretest, post-test designs as they appear to provide a good opportunity to test out naturebased solutions in a range of contexts and populations. This suggests that research favours natural experiments that enable observation of communities and populations with allocation of control. As an assessment of effectiveness rather than efficiency, natural experiments may also provide opportunity for external validity and local meaningful generalisation. ${ }^{109}$ However, challenges associated with refining nature-based interventions and controlling confounders may have influenced the dearth noted in natural experiments within this review. The lack of definition limited the ability of the review to categorise gardens and gardening as typical interventions. Ultimately, this also resulted in a plethora of methods used to examine the impact of gardens, and limited opportunities for meta-analysis. The prevailing positivist paradigm needs to be revisited within this context and greater consideration proffered for the use of natural experiments or those that use mixed methods to demonstrate impact rather than causality. Hence, natural experiments that include mixed methods are a potential solution to this methodological quagmire that exists within contemporary evidence for complex nature-based interventions.

The multiple benefits reported in this scoping review illustrate the breadth of the literature, and highlight the benefits of gardens and gardening on diverse populations. This has wider implications for healthcare practitioners and can offer non-clinical solutions that build on traditional asset-based community approaches. Our findings suggest that socially prescribed referrals to gardens and gardening have the potential to change people's behaviours and activate well-being. In addressing the wider determinants of health, social prescriptions using nature-based solutions could help improve mental, physical and physiological outcomes, ultimately influencing a potential to minimise inappropriate GP consultations and $\mathrm{A} \& \mathrm{E}$ attendance and improve resilience. As a social prescription, nature-based solutions, such as gardening, provide clinicians with an evidence-based opportunity to promote well-being through non-medical methods.

\section{CONCLUSIONS}

A strength of our scoping review was its rigorous and systematic approach to locate and understand the breadth of evidence reporting the effects of gardens and gardening on people with LTCs. The scoping review has exposed a myriad of paradigmatic solutions that have been used to capture well-being outcomes. Irrespective of the heterogeneous methods used, our scoping review indicates that gardens and gardening could have a positive dual benefit on a range of mental, social and psychological outcomes, and thus, may be of relevance to those considering gardens and gardening as a nonmedical, social prescription. Our logic models could be used as a decision support aid to enable more confident referral to nature-based solutions as part of a wider social prescription.

\section{Author affiliations}

${ }^{1}$ School of Health and Society, University of Salford, Salford, UK

${ }^{2}$ School of Science, Engineering and Environment, University of Salford, Salford, UK

${ }^{3}$ Department of Health Services Research, University of Liverpool, Liverpool, UK

Contributors $\mathrm{MH}, \mathrm{AB}, \mathrm{MH}, \mathrm{MM}$ made substantial contributions to the conception or design of the work and drafted the work and provided final approval of the version to be published.

Funding The authors have not declared a specific grant for this research from any funding agency in the public, commercial or not-for-profit sectors.

Competing interests None declared.

Patient consent for publication Not required.

Provenance and peer review Not commissioned; externally peer reviewed.

Data availability statement Data are available upon reasonable request. No primary data were used. The search protocol is available on request. 
Open access This is an open access article distributed in accordance with the Creative Commons Attribution Non Commercial (CC BY-NC 4.0) license, which permits others to distribute, remix, adapt, build upon this work non-commercially, and license their derivative works on different terms, provided the original work is properly cited, appropriate credit is given, any changes made indicated, and the use is non-commercial. See: http://creativecommons.org/licenses/by-nc/4.0/.

ORCID iD

Michelle Howarth http://orcid.org/0000-0003-4521-024X

\section{REFERENCES}

1 World Health Organisation. Global health observatory NCD morality and morbidity, 2017. Available: http://www.who.int/gho/ncd/ mortality_morbidity/en/ [Accessed 14 Sept 2017].

2 World Health Organization. Mental health action plan 2013-2020, 2013. Available: https://apps.who.int/iris/handle/10665/89966

3 Koh HK, Bantham A, Geller AC, Koh Howard K,M.D, Bantham $\mathrm{MPH}$, Amy MS, et al. Anchor institutions: best practices to address social needs and social determinants of health. Am J Public Health 2020;110:309-16.

4 Mcmanus S, Bebbington P, Jenkins R. Mental health and wellbeing in England: adult psychiatric morbidity survey 2014, 2016. Available: Http://Content.Digital.Nhs.Uk/Catalogue/ Pub21748/Apms-2014Full-Rpt.Pdf[Accessed 7 Aug 2017].

5 Cruwys T, Wakefield JRH, Sani F, Dingle GA J, et al. Social isolation predicts frequent attendance in primary care. Ann Behav Med 2018;52:817-29.

6 Henry H, Howarth ML. An overview of using an asset-based approach to nursing. Gen Pract Nurs 2018;4:61-6.

7 Bickerdike L, Booth A, Wilson PM, et al. Social prescribing: less rhetoric and more reality. A systematic review of the evidence. BMJ Open 2017;7:e013384-17.

8 Polley MJ, Pilkington K. A review of the evidence assessing impact of social prescribing on healthcare demand and cost implications. University of Westminster, 2017.

9 Howarth M, Rogers M, Withnell N, et al. Growing spaces: an evaluation of the mental health recovery programme using mixed methods. J Res Nurs 2018;23:476-89.

10 Croft B. Self-direction and the social determinants of health Community Ment Health J 2020;26.

11 Soga M, Gaston KJ, Yamaura Y. Gardening is beneficial for health: a meta-analysis. Prev Med Rep 2017:5:92-9.

12 Collins CC, O'Callaghan AM. The impact of horticultural responsibility on health indicators and quality of life in assisted living. Horttechnology 2008;18:611-8.

13 Wiskerke JSC, Viljoen A. Sustainable Urban Food Provisionning: Challenges for Scientists, Policymakers, Planners and Designers. In: Viljoen A, Wiskerke JSC, eds. Sustainable food planning: evolving theory and practice. Wageningen: Wageningen Academic Publishers, 2012.

14 Hardman M, Larkham PJ. Informal urban agriculture. Berlin: Springer, 2014.

15 Holland L. Diversity and connections in community gardens: a contribution to local sustainability, local environment. Int J Justice Sustainability 2004;9:285-305

16 Munn Z, Peters MDJ, Stern C, et al. Systematic review or scoping review? guidance for authors when choosing between a systematic or scoping review approach. BMC Med Res Methodol 2018;18:143.

17 Arksey H, O'Malley L. Scoping studies: towards a methodological framework. Int J Soc Res Methodol 2005;8:19-32.

18 Midlands and Lancashire Commissioning Support Unit. Using logic models. Available: Https://Midlandsandlancashirecsu.Nhs.Uk/ News-Insight/Press-Releases/236-Using-Logic-Models [Accessed 1 Sept 2017].

19 Levac D, Colquhoun H, O'Brien KK. Scoping studies: advancing the methodology. Implement Sci 2010;5:69.

20 Daudt HML, van Mossel C, Scott SJ. Enhancing the scoping study methodology: a large, inter-professional team's experience with Arksey and O'Malley's framework. BMC Med Res Methodol 2013;13:48

21 Buck D. Gardens and health: implications for policy and practice. London: Kings Fund, 2016.

22 Craig P, Diepe P, Macintyre S, et al. Medical Research Council (MRC) developing and evaluating complex interventions. London: MRC, 2006.

23 Muir Gray JA. Evidence-based Healthcare. In: How to make health policy and management decisions. 2 edn. Churchill-Livingstone, 2001.
24 Moher D, Liberati A, Tetzlaff J, et al. Preferred reporting items for systematic reviews and meta-analyses: the PRISMA statement. PLoS Med 2009;6:e1000097.

25 Al-Delaimy WK, Webb M. Community gardens as environmental health interventions: benefits versus potential risks. Curr Environ Health Rep 2017;4:252-65.

26 Annerstedt M, Währborg P. Nature-assisted therapy: systematic review of controlled and observational studies. Scand J Public Health 2011;39:371-88.

27 Austin EN, Johnston YAM, Morgan LL. Community gardening in a senior center: a therapeutic intervention to improve the health of older adults. Ther Recreation J 2006:40:48-57.

28 Bail JR, Frugé AD, Cases MG, et al. A home-based mentored vegetable gardening intervention demonstrates feasibility and improvements in physical activity and performance among breast cancer survivors. Cancer 2018;124:3427-35.

29 Blair CK, Madan-Swain A, Locher JL, et al. Harvest for health gardening intervention feasibility study in cancer survivors. Acta Oncol 2013;52:1110-8.

30 Bragg R, Atkins G. A review of nature-based interventions for mental health care, 2016.

31 Christian MS, Evans CEL, Cade JE. Does the royal horticultural society campaign for school gardening increase intake of fruit and vegetables in children? results from two randomised controlled trials. Public Health Res;2:1-162.

32 Cipriani J, Benz A, Holmgren A, et al. A systematic review of the effects of horticultural therapy on persons with mental health conditions. Occupational Therapy in Mental Health 2017;33:47-69.

33 Clatworthy J, Hinds J, M. Camic P. Gardening as a mental health intervention: a review. Ment Health Review J 2013;18:214-25.

34 D'Andrea SJ, Batavia M, Sasson N. Effect of horticultural therapy on preventing the decline of mental abilities of patients with Alzheimer's type dementia. J Ther Hortic 2007:18.

35 Detweiler MB, Self JA, Lane S, et al. Horticultural therapy: a pilot study on modulating cortisol levels and indices of substance craving, posttraumatic stress disorder, depression, and quality of life in veterans. Altern Ther Health Med 2015;21:36-41.

36 Dewi N, Komatsuzaki M, Yamakawa Y, et al. Community gardens as health promoters: effects on mental and physical stress levels in adults with and without mental disabilities. Sustainability 2017;9:63.

37 Dunnett N, Qasim M. Perceived benefits to human well-being of urban gardens. Horttechnology 2000;10:40-5.

38 Edwards CA, McDonnell C, Merl H. An evaluation of a therapeutic garden's influence on the quality of life of aged care residents with dementia. Dementia 2013;12:494-510.

39 Eriksson T, Westerberg Y, Jonsson $\mathrm{H}$. Experiences of women with stress-related ill health in a therapeutic gardening program. Can $\mathrm{J}$ Occup Ther 2011;78:273-81.

40 Farrier A, Baybutt M, Dooris M. Mental health and wellbeing benefits from a prisons horticultural programme. Int $J$ Prison Health 2019:15:91-104.

41 Ford Murphy P, Miyazaki Y, Detweiler MB, et al. Longitudinal analysis of differential effects on agitation of a therapeutic wander garden for dementia patients based on ambulation ability. Dementia 2010;9:355-73.

42 Garcia MT, Ribeiro SM, Germani ACCG, et al. The impact of urban gardens on adequate and healthy food: a systematic review. Public Health Nutr 2018;21:416-25.

43 Gatto NM, Martinez LC, Spruijt-Metz D, et al. La sprouts randomized controlled nutrition, cooking and gardening programme reduces obesity and metabolic risk in Hispanic/Latino youth. Pediatr Obes 2017:12:28-37.

44 Genter C, Roberts A, Richardson J, et al. The contribution of allotment gardening to health and wellbeing: a systematic review of the literature. Br J Occup Ther 2015;78:593-605.

45 Gonzalez MT, Hartig T, Patil GG, et al. Therapeutic horticulture in clinical depression: a prospective study. Res Theory Nurs Pract 2009;23:312-28.

46 Han A-R, Park S-A, Ahn B-E. Reduced stress and improved physical functional ability in elderly with mental health problems following a horticultural therapy program. Complement Ther Med 2018;38:19-23.

47 Harris N, Minniss FR, Somerset S. Refugees connecting with a new country through community food gardening. Int $J$ Environ Res Public Health 2014;11:9202-16.

48 Hartwig KA, Mason M. Community gardens for refugee and immigrant communities as a means of health promotion. $J$ Community Health 2016:41:1153-9.

49 Hawkins JL, Thirlaway KJ, Backx K, et al. Allotment gardening and other leisure activities for stress reduction and healthy aging. Horttechnology 2011;21:577-85. 
50 Hawkins JL, Smith A, Backx K, et al. Exercise intensities of gardening tasks within older adult allotment gardeners in Wales. $J$ Aging Phys Act 2015;23:161-8.

51 Heim S, Bauer KW, Stang J, et al. Can a community-based intervention improve the home food environment? parental perspectives of the influence of the Delicious and nutritious garden. J Nutr Educ Behav 2011:43:130-4.

52 Heliker D, Chadwick A, O'Connell T. The meaning of gardening and the effects on perceived well being of a gardening project on diverse populations of elders. Act Adapt Aging 2001;24:35-56.

53 Hernandez RO. Effects of therapeutic gardens in special care units for people with dementia. J Hous Elderly 2007;21:117-52.

54 Hewitt P, Watts C, Hussey J, et al. Does a structured gardening programme improve well-being in young-onset dementia? A preliminary study. Br J Occup Ther 2013;76:355-61.

55 Jarrott SE, Gigliotti CM. Comparing responses to horticulturalbased and traditional activities in dementia care programs. Am J Alzheimers Dis Other Demen 2010;25:657-65.

56 Jarrott SE, Kwack HR, Relf D. An observational assessment of a dementia-specific horticultural therapy program. Horttechnology 2002;12:403-10.

57 Jeong M-H, Lee I-S, Chung Y-M, et al. Effect of horticultural therapy on improvement of mental health and social adaptability of Schizoid of the open ward. Korean J Hortic Sci Techno/2004;22:499-503.

58 Joyce J, Warren A. A case study exploring the influence of a gardening therapy group on well-being. Occup Ther Mental Health 2016;32:203-15.

$59 \mathrm{MCY}$ K, AMH S. Evaluation of a horticultural activity programme for persons with psychiatric illness. Hong Kong J Occup Ther

60 Kamioka H, Tsutani K, Yamada M, et al. Effectiveness of horticultural therapy: a systematic review of randomized controlled trials. Complement Ther Med 2014;22:930-43.

61 Kim MY, Kim GS, Mattson NS, et al. Effects of horticultural occupational therapy on the physical and psychological rehabilitation of patients with hemiplegia after stroke. Korean $J$ Hortic Sci Technol 2010;28:884-90.

62 Kohlleppel T, Bradley JC, Jacob S. A walk through the garden: can a visit to a botanic garden reduce stress? Horttechnology 2002;12:489-92.

63 Korpela K, De Bloom J, Sianoja M, et al. Nature at home and at work: naturally good? links between window views, indoor plants, outdoor activities and employee well-being over one year. Landsc Urban Plan 2017;160:38-47.

64 Kunpeuk W, Spence W, Phulkerd S, et al. The impact of gardening on nutrition and physical health outcomes: a systematic review and meta-analysis. Health Promot Int 2020;35:397-408.

65 Lai CKY, Kwan RYC, Lo SKL, CKY L, Lo SKL FCYY, et al. Effects of horticulture on frail and Prefrail nursing home residents: a randomized controlled trial. J Am Med Dir Assoc 2018;19:696-702.

66 Lai CK-Y, Lau CK-Y, Kan WY, et al. The effect of horticultural therapy on the quality of life of palliative care patients. $J$ Psychosoc Oncol 2017;35:278-91.

$67 \mathrm{Ga}$ L, Gupta A. Gardening increases vegetable consumption in school-aged children: a meta-analytical synthesis. Horttechnology 2012;22:430-45.

68 Lanier J, Schumacher J, Calvert K. Cultivating community collaboration and community health through community gardens. $J$ Community Pract 2015;23:492-507.

69 Lee Y, Kim S. Effects of indoor gardening on sleep, agitation, and cognition in dementia patients--a pilot study. Int J Geriatr Psychiatry 2008;23:485-9.

70 Lêng $\mathrm{CH}$, Wang J-D. Daily home gardening improved survival for older people with mobility limitations: an 11-year follow-up study in Taiwan. Clin Interv Aging 2016;11:947-59.

71 Wen Li W, Hodgetts D, Ho E, WW L, Gardens HE. Gardens, transitions and identity reconstruction among older Chinese immigrants to new Zealand. J Health Psychol 2010;15:786-96.

72 Liu Y, Li B, Sampson SJ, et al. Horticultural therapy for schizophrenia. Cochrane Database Syst Rev 2014;20.

73 Lu L-C, Lan S-H, Hsieh Y-P, et al. Horticultural therapy in patients with dementia: a systematic review and meta-analysis. Am J Alzheimers Dis Other Demen 2020;35:1533317519883498.

74 Luk KY, Lai KYC, Li CC, et al. The effect of horticultural activities on agitation in nursing home residents with dementia. Int J Geriatr Psychiatry 2011;26:435-6.

75 Masset E, Haddad L, Cornelius A, et al. Effectiveness of agricultural interventions that aim to improve nutritional status of children: systematic review. BMJ 2012;344:d8222.

76 Masuya J, Ota K. Efficacy of horticultural activity in elderly people with dementia: a pilot study on the influence on vitality and cognitive function. Int J Nurs Clin Pract 2014;1.
77 Masuya J, Ota K, Mashida Y. The effect of a horticultural activities program on the psychologic, physical, cognitive function and quality of life of elderly people living in nursing homes. Int $J$ Nurs Clin Pract 2014:1.

78 Matsunaga K, Park B-J, Kobayashi $\mathrm{H}$, et al. Physiologically relaxing effect of a hospital rooftop forest on older women requiring care. $J$ Am Geriatr Soc 2011:59:2162-3.

79 McCaffrey R. The effect of healing gardens and art therapy on older adults with mild to moderate depression. Holist Nurs Pract 2007;21:79-84.

80 McCaffrey R, Hanson C, McCaffrey W. Garden walking for depression: a research report. Holist Nurs Pract 2010;24:252-9.

81 McCaffrey R, Liehr P. The effect of reflective garden walking on adults with increased levels of psychological stress. J Holist Nurs 2016;34:177-84.

82 Milligan C, Gatrell A, Bingley A. "Cultivating health": therapeutic landscapes and older people in northern England. Soc Sci Med 2004;58:1781-93.

83 Nicholas SO, Giang AT, Yap PLK. The effectiveness of horticultural therapy on older adults: a systematic review. J Am Med Dir Assoc 2019;20:1351

84 Nicklett EJ, Anderson LA, Yen IH. Gardening activities and physical health among older adults: a review of the evidence. $J$ Appl Gerontol 2016;35:678-90.

85 Oh Y-A, Park S-A, Ahn B-E. Assessment of the psychopathological effects of a horticultural therapy program in patients with schizophrenia. Complement Ther Med 2018;36:54-8.

86 Ohly H, Gentry S, Wigglesworth R, et al. A systematic review of the health and well-being impacts of school gardening: synthesis of quantitative and qualitative evidence. BMC Public Health 2016;16:286.

87 Park S-A, Lee A-Y, Park H-G, et al. Gardening intervention as a low- to moderate-intensity physical activity for improving blood lipid profiles, blood pressure, inflammation, and oxidative stress in women over the age of 70: a pilot study. HortScience 2017;52:200-5.

88 Robinson-O'Brien R, Story M, Heim S. Impact of garden-based youth nutrition intervention programs: a review. J Am Diet Assoc 2009; 109:273-80.

89 Rodiek S. Influence of an outdoor garden on mood and stress in older persons. J Ther Hortic 2002;13:13-21.

90 Savoie-Roskos MR, Wengreen H, Durward C. Increasing fruit and vegetable intake among children and youth through gardeningbased interventions: a systematic review. J Acad Nutr Diet 2017; $117: 240-50$

91 Scott TL, Masser BM, Pachana NA. Exploring the health and wellbeing benefits of gardening for older adults. Ageing Soc 2015;35:2176-200.

92 Sempik J, Rickhuss C, Beeston A. The effects of social and therapeutic horticulture on aspects of social behaviour. Br J Occup Ther 2014;77:313-9.

93 Soga M, Cox DTC, Yamaura Y, et al. Health benefits of urban allotment gardening: improved physical and psychological wellbeing and social integration. Int J Environ Res Public Health $2017 ; 14: 71$

94 Stern C, Munn Z. Cognitive leisure activities and their role in preventing dementia: a systematic review. Int J Evid Based Healthc 2010;8:2-17.

95 Swank JM, Shin SM. Garden counseling groups and self-esteem: a mixed methods study with children with emotional and behavioral problems. J Spe?c Group Work 2015;40:315-31.

96 Van Den Berg AE, Custers MHG. Gardening promotes neuroendocrine and affective restoration from stress. $J$ Health Psychol 2011;16:3-11

97 Wang D, MacMillan T. The benefits of gardening for older adults: a systematic review of the literature. Act Adapt Aging 2013;37:153-81.

98 Whear R, Coon JT, Bethel A, et al. What is the impact of using outdoor spaces such as gardens on the physical and mental wellbeing of those with dementia? A systematic review of quantitative and qualitative evidence. J Am Med Dir Assoc 2014;15:697-705.

99 Wood CJ, Pretty J, Griffin M. A case-control study of the health and well-being benefits of allotment gardening. J Public Health 2016;38:e336-44

100 Zick CD, Smith KR, Kowaleski-Jones L, et al. Harvesting more than vegetables: the potential weight control benefits of community gardening. Am J Public Health 2013;103:1110-5.

101 Mills T, Lawton R, Sheard L. Advancing complexity science in healthcare research: the logic of logic models. BMC Med Res Methodol 2019;19:55. 
102 Rohwer A, Pfadenhauer L, Burns J, et al. Series: clinical epidemiology in South Africa. paper 3: logic models help make sense of complexity in systematic reviews and health technology assessments. J Clin Epidemiol 2017;83:37-47.

103 Tennant R, Hiller L, Fishwick R, et al. The Warwick-Edinburgh mental well-being scale (WEMWBS): development and UK validation. Health Qual Life Outcomes 2007;5:63.

104 Aked J, Marks N, Cordon C, et al. Five ways to wellbeing: a report presented to the foresight project on communicating the evidence base for improving people's well-being. London: New Economics Foundation, 2008.

105 Dodge R, Daly A, Huyton J, et al. The challenge of defining wellbeing. Intnl. J Wellbeing 2012;2:222-35.

106 Howarth M, Lister C. Social prescribing in cardiology: rediscovering the nature within us. Br J Card Nurs 2019;14:1-9.
107 Cook PA, Howarth M, Wheater CP. Biodiversity and Health in the Face of Climate Change: Implications for Public Health. In: Marselle $\mathrm{M}$, Stadler J, Korn H, et al, eds. Biodiversity and health in the face of climate change. Springer Press, 2019.

108 Hajek A, Bock J-O, König H-H. Association of general psychological factors with frequent attendance in primary care: a population-based cross-sectional observational study. BMC Fam Pract 2017;18:48.

109 Petticrew M, Cummins S, Ferrell C, et al. Natural experiments: an underused tool for public health? Public Health 2005;119:751-7.

110110 Kam MCY, Siu AMH. Evaluation of a horticultural activity programme for persons with psychiatric illness. Hong Kong Journal of Occupational Therapy 2010;20:80-6. 